\title{
A Study on Individuals Perception towards Development of Digital Economy during COVID-19 Pandemic
}

\section{OPEN ACCESS \\ Manuscript ID: \\ COM-2021-09034124}

Volume: 9

Issue: 3

Month: July

Year: 2021

E-ISSN: 2582-6190

Received: 24.04.2021

Accepted: 05.06.2021

Published: 01.07.2021

Citation:

Srinivasan, KR, and

J. Duraichamy. "A Study on Individuals Perception towards Development of Digital Economy during COVID-19 Pandemic." ComFin Research, vol. 9, no. 3, 2021, pp. 11-15.

\section{DOI:}

https://doi.org/10.34293/ commerce.v9i3.4124

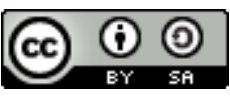

This work is licensed under a Creative Commons Attribution-ShareAlike 4.0 International License

\author{
K.R. Srinivasan \\ Assistant Professor \& Head, Department of Economics \\ Sourashtra College (A), Madurai, Tamil Nadu, India
}

\author{
J. Duraichamy \\ Assistant Professor, Department of Commerce \& Research Centre \\ Sourashtra College (A), Madurai, Tamil Nadu, India
}

\begin{abstract}
Developing country like India is facing major economical drawback because of out break of COVID-19 and it causes adverse effect on various sector like manufacturing auto, retail aviation and hospitality due to lock downs and migration of labours, on other side COVID-19 outbreak has helped India to achieve digitalization mission. In this study has been taken to know the positive impact of COVID-19 in development of digital economy in Tamilnadu. Objective of this study is to know the individual's perception towards increased usage of digital transactions on during COVID-19 pandemic and its impact on socio economic profile. 148 samples were collected with the help of questionnaire. SPSS package has been used to derive statistical inferences.
\end{abstract}

Keywords: Digital economy, Digital transactions, Perception

\section{Introduction}

The COVID-19 out break is indirectly helping India to achieve digital India vision, as many service providers slowly moving on to digital platform to reach their customers virtually. After pandemic India will permanently shift to digital transactions hence the consumers behaviour has changed and they preferred to shop online and it causes the enormous development in e-commerce. Rapid digitalization will drive economic recovery and helps to systematic approach to solve problems in an economy. Impact of digitalization can key sectors like health care, education and manufacturing sector will innovate success in future. In this study an attempt has been made to know the impact of digitalization among individuals and their perception towards increases in digital transactions.

\section{Objective of the Study}

- To analyse individuals' perception towards increased usage of digital transactions and development of digital economy

- To know the socio-economic profile of the sample respondents

- To compare the socio-economic profile of the respondents and the impact of digitalization

\section{Research Methodology}

The study is descriptive in nature; 148 respondents have been selected from various parts of TamilNadu. The method of convenient sampling has been used as the main purpose is to find perception towards increased usage of digital transactions and development of digital economy. The data has been collected in January to March 2021 by using a personally- administered questionnaire. 
The descriptive statistics have been calculated and results have been analysed by using the technique of one-way ANOVA (Analysis of Variance) two way Anova.

\section{Hypothesis}

- There is no effect of Educational Qualification and occupation on perception towards development of digital economy.

- There is no significant association between gender and the perception towards Increased Usage of Digital Transaction and Development of Digital Economy.

- There is no significant relationship between socio economic profile of the sample respondent and the impact of digitalization.

Table 1: Gender of the Respondents

\begin{tabular}{|l|c|c|}
\hline Classification & No. of respondents & Percentage \\
\hline Male & 112 & 75.7 \\
\hline Female & 36 & 24.3 \\
\hline Total & $\mathbf{1 4 8}$ & $\mathbf{1 0 0}$ \\
\hline
\end{tabular}

Table 1 indicates that majority of the respondents are male that is $76 \%$ of the respondents, $24 \%$ of them are female.

Table 2: Age of the Respondents

\begin{tabular}{|c|c|c|}
\hline Classification & No. of respondents & Percentage \\
\hline 18-30 years & 67 & 45.3 \\
\hline 31-40 years & 31 & 20.9 \\
\hline 40 years above & 50 & 33.8 \\
\hline Total & $\mathbf{1 4 8}$ & $\mathbf{1 0 0}$ \\
\hline
\end{tabular}

Table 6: Perception Towards Increased Usage of Digital Transaction and Development of Digital Economy

\begin{tabular}{|l|c|c|c|c|c|c|}
\hline \multicolumn{1}{|c|}{ Classification } & $\begin{array}{c}\text { Highly } \\
\text { aware }\end{array}$ & Aware & Neutral & Not aware & $\begin{array}{c}\text { Not at all } \\
\text { aware }\end{array}$ & Mean \\
\hline $\begin{array}{l}\text { Digitalization increases transparency in } \\
\text { transaction }\end{array}$ & $\begin{array}{c}19 \\
(12.8)\end{array}$ & $\begin{array}{c}47 \\
(31.8)\end{array}$ & $\begin{array}{c}58 \\
(39.2)\end{array}$ & $\begin{array}{c}18 \\
(12.2)\end{array}$ & $\begin{array}{c}8 \\
(4.1)\end{array}$ & 3.37 \\
\hline $\begin{array}{l}\text { Digitalization can reduce spreading of } \\
\text { disease and saves life }\end{array}$ & $\begin{array}{c}37 \\
(25)\end{array}$ & $\begin{array}{c}55 \\
(37.2)\end{array}$ & $\begin{array}{c}44 \\
(29.7)\end{array}$ & $\begin{array}{c}12 \\
(8.1)\end{array}$ & $\begin{array}{c}0 \\
(0)\end{array}$ & 3.79 \\
\hline $\begin{array}{l}\text { Digitalization helps to increase technical } \\
\text { skill among individuals }\end{array}$ & $\begin{array}{c}48 \\
(32.4)\end{array}$ & $\begin{array}{c}64 \\
(43.2)\end{array}$ & $\begin{array}{c}16 \\
(10.8)\end{array}$ & $\begin{array}{c}14 \\
(9.5)\end{array}$ & $\begin{array}{c}6 \\
(4.1)\end{array}$ & 3.85 \\
\hline $\begin{array}{l}\text { Digital transactions and digitalization of } \\
\text { services saves time }\end{array}$ & $\begin{array}{c}76 \\
(51.4)\end{array}$ & $\begin{array}{c}21 \\
(14.2)\end{array}$ & $\begin{array}{c}10 \\
(6.8)\end{array}$ & $\begin{array}{c}23 \\
(15.5)\end{array}$ & $\begin{array}{c}18 \\
(12.2)\end{array}$ & 3.77 \\
\hline $\begin{array}{l}\text { Digitalization reduces corruption and } \\
\text { black money }\end{array}$ & $\begin{array}{c}44 \\
(29.7)\end{array}$ & $\begin{array}{c}36 \\
(24.3)\end{array}$ & $\begin{array}{c}9 \\
(6.1)\end{array}$ & $\begin{array}{c}23 \\
(15.5)\end{array}$ & $\begin{array}{c}36 \\
(24.3)\end{array}$ & 2.8 \\
\hline
\end{tabular}

It is observed that majority of the respondents (35\%) has qualification up to high school.

Table 4: Occupation of the Respondents

\begin{tabular}{|c|c|c|}
\hline Classification & No. of respondents & Percentage \\
\hline Casual Labour & 51 & 34.5 \\
\hline Unemployed & 28 & 18.9 \\
\hline Private Employee & 37 & 25 \\
\hline Self Employed & 32 & 21.6 \\
\hline Total & 148 & 100 \\
\hline
\end{tabular}
respondents are casual labours.

Table 5: Monthly Income

\begin{tabular}{|l|c|c|}
\hline \multicolumn{1}{|c|}{ Classification } & No. of respondents & Percentage \\
\hline No regular income & 44 & 29.7 \\
\hline Less than 5000 & 30 & 20.3 \\
\hline 5000 to 15000 & 38 & 25.7 \\
\hline More than 15000 & 36 & 24.3 \\
\hline Total & $\mathbf{1 4 8}$ & $\mathbf{1 0 0}$ \\
\hline
\end{tabular}

It is observed that majority of the respondents $(30 \%)$ has no regular income.
It is observed from the table 2 that majority among 148 respondents $45 \%$ are between the age group of 31 to 40 years.

Table 3: Literacy level of the Respondents

\begin{tabular}{|c|c|c|}
\hline Classification & No. of respondents & Percentage \\
\hline Primary School & 15 & 10.1 \\
\hline High School & 92 & 62.2 \\
\hline UG & 12 & 8.1 \\
\hline PG & 29 & 19.6 \\
\hline Total & 148 & 100 \\
\hline
\end{tabular}

\section{,}


According to mean score secured by variables highest mean 3.79 is secured by the variable digitalisation can reduce spreading of disease and can save life of the individual, second mean score 3.77 secured by digital transactions and digitalization of services saves time of the individual. It is concluded that individual has higher perception towards digitalisation can reduce spreading of disease and can save life of individual.

\section{Hypothesis 1}

\section{Two Way ANOVA}

The significant effects of Educational Qualification Category and occupation Category on the perception towards development of digital economy have been statistically analysed by using Two-way ANOVA. For this purpose, the researcher has framed the following hypothesis:

There is no effect of Educational Qualification and occupation onperception towards development of digital economy.

Table 7: Effects of Educational Qualification and Occupation on the perception towards Increased Usage of Digital Transaction and Development of Digital Economy

\begin{tabular}{|c|c|c|c|c|c|}
\hline \multicolumn{6}{|c|}{ Tests of Between-Subjects Effects } \\
\hline Source & $\begin{array}{c}\text { Type } \\
\text { III } \\
\text { Sum of } \\
\text { Squares }\end{array}$ & $\begin{array}{c}\text { Mean } \\
\text { square }\end{array}$ & $\mathbf{F}$ & Sig. & SI \\
\hline \multicolumn{6}{|c|}{ Dependent Variable } \\
\hline $\begin{array}{l}\text { Educational } \\
\text { Qualification }\end{array}$ & 17.502 & 5.834 & 1.58 & 0.196 & \\
\hline Occupation & 25.93 & 8.645 & 2.34 & 0.076 & \\
\hline $\begin{array}{l}\text { Educational } \\
\text { Qualification } \\
\text { * Occupation }\end{array}$ & 9.454 & 1.351 & 0.367 & 0.920 & NS \\
\hline Error & 493.6 & 3.684 & & & \\
\hline
\end{tabular}

SI: Statistical Inference; NS: Not Significant

Source: Computed from Primary Data;

Inference: The table indicates that, the p-values of all Educational Qualification Levels (0.196, 0.076 and 0.920$)$ are $>0.05$; This shows that both main effects and the interaction effects of Educational Qualification and occupation on the perception towards development of digital economy are not statistically significant. This explain that, there are no significant differences in the perception towards development of digital economy between Educational Qualification Levels as well as between employees working in Top and Middle Level Category. The adjusted R Squared tells us that more than $1 \%$ of the variance in perception towards development of digital economy. Since this is a very low value, indicating poor no relationships between our educational qualification and occupation and the Increased Usage of Digital Transaction and Development of Digital Economy.

\section{Hypothesis 2}

There is no significant association between gender and the perception towards Increased Usage of Digital Transaction and Development of Digital Economy.

Table 8: Gender and Perception towards Increased Usage of Digital Transaction and Development of Digital Economy

\begin{tabular}{|l|c|c|c|c|}
\hline \multicolumn{1}{|c|}{ Impact } & \multicolumn{1}{|c|}{$\begin{array}{c}\text { F } \\
\text { value }\end{array}$} & $\begin{array}{c}\text { P } \\
\text { value }\end{array}$ & $\begin{array}{c}\text { Statistical } \\
\text { inference }\end{array}$ & Result \\
\hline $\begin{array}{l}\text { Digitalization } \\
\text { increases } \\
\text { transparency in } \\
\text { transaction }\end{array}$ & $10.072^{\mathrm{a}}$ & 0.018 & $\begin{array}{c}\mathrm{p} \text { value }< \\
0.05\end{array}$ & $\mathrm{~S}$ \\
\hline $\begin{array}{l}\text { Digitalization can } \\
\text { reduce spreading } \\
\text { of disease and } \\
\text { saves life }\end{array}$ & $23.407^{\mathrm{a}}$ & 0.000 & $\begin{array}{c}\mathrm{p} \text { value }< \\
0.05\end{array}$ & $\mathrm{~S}$ \\
\hline $\begin{array}{l}\text { Digitalization } \\
\text { helps to increase } \\
\text { technical } \\
\text { skill among } \\
\text { individuals }\end{array}$ & $68.120^{\mathrm{a}}$ & 0.000 & $\mathrm{p}$ value $<$ \\
0.05 & $\mathrm{~S}$ \\
\hline $\begin{array}{l}\text { Digital } \\
\text { transactions and } \\
\text { digitalization of } \\
\text { services saves } \\
\text { time }\end{array}$ & $25.804^{\mathrm{a}}$ & 0.000 & $\mathrm{p} \mathrm{value}<$ & $\mathrm{S}$ \\
\hline $\begin{array}{l}\text { Digitalization } \\
\text { reduces } \\
\text { corruption and } \\
\text { black money }\end{array}$ & $27.761^{\mathrm{a}}$ & 0.000 & $\mathrm{p}$ value $<$ \\
0.05 & $\mathrm{~S}$ \\
\hline
\end{tabular}

Source: Primary data 
Inference: Table indicates that there is a significant association between gender and the level of perception towards development of digital economy. Since level of significance is less than 0.05 (p value $<0.05)$ null hypothesis rejected,

Hence it is concluded that there is a significant association between gender and perception towards increased usage of digital transaction and development of digital economy

\section{Hypothesis 3}

There is no significant relationship between socio economic profile of the sample respondent and the impact of digitalization.

Table 9: Socio Economic Profile and the Impact of Digital Transaction

\begin{tabular}{|l|c|c|c|c|}
\hline $\begin{array}{c}\text { Socio } \\
\text { Economic } \\
\text { Profile }\end{array}$ & $\begin{array}{c}\text { F } \\
\text { value }\end{array}$ & $\begin{array}{c}\text { P } \\
\text { value }\end{array}$ & $\begin{array}{c}\text { Statistical } \\
\text { inference }\end{array}$ & Result \\
\hline Gender & 1.070 & 0.000 & $\begin{array}{c}\mathrm{p} \text { value }< \\
0.05\end{array}$ & $\mathrm{~S}$ \\
\hline Age & 10.899 & 0.000 & $\begin{array}{c}\mathrm{p} \text { value }< \\
0.05\end{array}$ & $\mathrm{~S}$ \\
\hline Qualification & 9.743 & 0.000 & $\begin{array}{r}\mathrm{p} \text { value }< \\
0.05\end{array}$ & $\mathrm{~S}$ \\
\hline Salary & 29.820 & 0.000 & $\begin{array}{r}\mathrm{p} \text { value }< \\
0.05\end{array}$ & $\mathrm{~S}$ \\
\hline Marital Status & 10.359 & 0.000 & $\begin{array}{c}\mathrm{p} \text { value }< \\
0.05\end{array}$ & $\mathrm{~S}$ \\
\hline
\end{tabular}

Source: Primary data

Table 9 indicates that there is a significant relationship between socio economic profile of the sample respondents and impact of digital transaction. Since $\mathrm{p}$ value $<0.05$ null hypothesis rejected.

\section{Findings}

- Majority of the respondents are male that is 76 $\%$ of the respondents, $24 \%$ of them are female.

- Majority among 148 respondents $45 \%$ are between the age group of 31 to 40 years.

- Majority of the respondents (35\%) has qualification up to high school.

- Majority $34 \%$ of the respondents are casual labours.

- Majority of the respondents (30\%) has no regular income.
- Individual has higher perception towards digitalisation can reduce spreading of disease and can save life of individual.

- The p-values of all Educational Qualification Levels $(0.196,0.076$ and 0.920$)$ are $>0.05$; This shows that both main effects and the interaction effectsofEducationalQualificationandoccupation on the perception towards development of digital economy are not statistically significant. This explain that, there are no significant differences in the perception towards development of digital economy between Educational Qualification Levels as well as between employees working in Top and Middle Level Category. The adjusted $\mathrm{R}$ Squared tells us that more than $1 \%$ of the variance in perception towards development of digital economy. Since this is a very low value, indicating poor no relationships between our educational qualification and occupation and the Increased Usage of Digital Transaction and Development of Digital Economy

- There is a significant association between gender and perception towards increased usage of digital transaction and development of digital economy

- There is a significant relationship between socio economic profile of the sample respondents and impact of digital transaction. since $p$ value is less than 0.05 null hypothesis rejected.

\section{Conclusion}

From the study it is concluded that male respondents are highly interested in digitalization than female hence it reduced their physical transportation effort for house hold activity and the female opinion is totally different than male respondents. Perception towards increased usage of digital transaction can reduce physical handling of cash which also prevents from virus spreads and save life of the individual in current situations. Digitalization causes higher impact in the life style of the individual in Tamilnadu and it will help the government to recover from economic crises after and during COVID-19 pandemic situation. Due to increased usage of digitalization flow of cash commerce and other business got new opportunity and they are getting ready to face upcoming digital transformations as well. 
References

"COVID-19 has Changed Online Shopping Forever, Survey Shows." UNCTAD, 2020.

"COVID-19 is Accelerating the Rise of the Digital Economy." BDO, 2020.

De, Rahul, et al. "Impact of Digital Surge during Covid-19 Pandemic: A Viewpoint on Research and Practice." International Journal of Information Management, vol. 55, 2020.

Jiang, Xiaojuan. "Digital Economy in the PostPandemic Era." Journal of Chinese Economic and Business Studies, vol. 18, no. 4, 2020, pp. 333-339.

Kaul, Mrinalini, and Purvi Mathur. "Impact of Digitalization on the Indian Economy and Requirement of Financial Literacy." Proceedings of International Conference on Recent Innovations in Engineering and Technology, 2017, pp. 100-105.

Mukhopadhyay, Bappaditya. "Understanding Cashless Payments in India." Financial Innovation, 2016.

Sidhu, Navpreet Singh. "Perception and Acceptability of Electronic Banking: A Study of the Customers of Selected Banks." International Journal of Social Science \& Interdisciplinary Research, vol. 2, no. 6, 2013, pp. 45-57.

Value Creation and Capture: Implications for Developing Countries. Digital Economy Report, United Nations, 2019.

\section{Author Details}

K.R. Srinivasan, Assistant Professor \& Head, Department of Economics, Sourashtra College (A), Madurai, Tamil Nadu, India

J. Duraichamy, Assistant Professor, Department of Commerce \& Research Centre, Sourashtra College (A), Madurai, Tamil Nadu, India 